that form the right to health care. In addition, the ambulance system, e-medicine and transplantation are still not provided with a proper legal basis, which should create a basis for their full reset. Thus, there is no question of the effectiveness and proper possibility of exercising the right to health care by individual patients belonging to socially vulnerable categories. A promising area for further research is the issue of regulatory and legal support of human mental health and support of its social activity by public law. lation.

Keywords: healthcare, right to health care, medical reform, legal means, medical care, legis-

DOI: 10.33766/2524-0323.91.195-205 УДК342.951[615: 614.2]
О. С. Ховпун,

кандидат юридичних наук, доцент, завідувач кафедри кримінального права,

процесу та криміналістики Академії праці, соціальних відносин і туризму (м. Київ, Україна)

e-mail: khovpun3322@gmail.com iDhttps://orcid.org/0000-0002-5753-966X

\title{
АДМІНІСТРАТИВНО-ПРАВОВІ ЗАСАДИ ЗДІЙСНЕННЯ МЕДИЧНОЇ ТА ФАРМАЦЕВТИЧНОЇ ДІЯЛЬНОСТІ В УКРАЇНІ
}

Статтю присвячено правовим засадам здійснення медичної і фармацевтичної діяльності в Україні. Визначені поняття медичної і фармацевтичної діяльності. Наведені законодавчі і підзаконні акти, які регулюють ліцензування цієї діяльності, правовий статус медичних і фармацевтичних працівників, закладів охорони здоров'я, фармацевтичних організацій, специфіку державного нагляду й державного управління у вказаних сферах суспільного життя.

3'ясовано, що спеціальними нормативно-правовими актами, які встановлюють особливості ліцензування медичної і фармацевтичної діяльності $є$ відповідні Ліцензійні умови провадження кожного з видів такої діяльності. Вони закріплюють організаційні, технологічні та кадрові вимоги до закладів охорони здоров'я і фармацевтичних організацій. Визначено нормативні засади правового статусу медичних і фармацевтичних працівників. Акцентовано увагу на нормативній основі для притягнення до кримінальної відповідальності за неналежне виконання своїх професійних обов' язків.

Ключові слова: правове регулювання, медична діяльність, фармацевтична діяльність, ліцензування, правовий статус.

Постановка проблеми. Належне правове регулювання будь-якого виду господарської діяльності є запорукою забезпечення дотримання прав і законних інтересів громадян під час надання певних послуг або виконання робіт. Ефективне правове регулювання медичної і фармацевтичної діяльності є засобом забезпечення прав пацієнта в закладах охорони здоров'я та прав споживача в аптеці.

Вважаємо, що визначення правових засад здійснення медичної і фармацевтичної діяльності дозволить встановити напрями подалышого вдосконалення законо-

(C) Ховпун О. С., 2020 
давства, яке регулює цю сферу правовідносин. Саме тому вивчення специфіки правового регулювання медичної і фармацевтичної діяльності $є$ актуальною темою наукового дослідження.

Аналіз останніх досліджень і публікацій. Підгрунтям роботи слугувало широке використання правових джерел. Так нормативну основу дослідження склали чинне законодавство України у сфері медичної і фармацевтичної діяльності. Стосовно ж наукових доробок, то варто означити, що проблеми правового регулювання медичної та фармацевтичної діяльності періодично стають предметом наукових досліджень окремих учених. Зокрема, 3. В. Загиней та Л. І. Шмаль вивчали сутність медичної практики як дозволеного виду діяльності в антикорупційному законодавстві України [1, с. 51-66]. А. М. Коваль досліджувала правове регулювання отримання медичної допомоги та медичних послуг [2, с. 94-99]. С. В. Васильєв присвятив своє дослідження визначенню поняття «фармацевтична діяльність» [3, с. 14-20]. В. I. Теремецький (у співавторстві з іншими вченими) здійснив порівняльно-правове дослідження відповідальності у сфері охорони здоров'я в країнах ЄС та України, а також визначив шляхи вдосконалення національного законодавства [4]. Указані науковці характеризували правове регулювання у сфері охорони здоров'я та пропонували власні визначення понять медичної діяльності та/або фармацевтичної діяльності. Водночас правове регулювання цих видів діяльності в умовах проведення нового етапу медичної реформи лише частково було предметом їхніх наукових досліджень. Саме тому дослідження особливостей адміністративно-правових засади здійснення медичної і фармацевтичної діяльності в Україні є важливим напрямом наукових досліджень і слугує вдосконаленню вітчизняних підходів до означеної діяльності.

Формулювання цілей. Мета статті полягає у визначенні правових засад здійснення медичної і фармацевтичної діяльності в Україні.

Виклад основного матеріалу. Характеризуючи правову основу медичної і фармацевтичної діяльності в Україні, необхідно навести визначення такої діяльності, які містяться в законодавчих актах та працях науковців.

Як передбачено в абз. 3 ч. 1 ст. 3 Основ законодавства України про охорону здоров'я, медична допомога - це діяльність професійно підготовлених медичних працівників, спрямована на профілактику, діагностику, лікування та реабілітацію у зв' язку iз хворобами, травмами, отруєннями й патологічними станами, а також у зв'язку із вагітністю та пологами [5]. Отже, указаний законодавчий акт використовує поняття «медичне обслуговування» та «медична допомога», а не «медична діяльність».

Згідно з абз. 2 п. 4 Ліцензійних умов провадження господарської діяльності 3 медичної практики, затверджених постановою Кабінету Міністрів України (далі Кабмін) від 02 березня 2016 року (далі - Ліцензійні умови медичної діяльності), господарська діяльність з медичної практики - вид господарської діяльності у сфері охорони здоров' я, який провадиться закладами охорони здоров' я та фізичними особами-підприємщями 3 метою надання медичної допомоги та медичного обслуговування на підставі ліцензії [6]. Зауважимо, що в цьому підзаконному акті використовується термін «медична практика», а не «медична діяльність». З. В. Загиней стверджує, що медична практика характеризується такими істотними ознаками: а) наявність ліцензії на здійснення медичної практики; б) здійснення діяльності у сфері 
охорони здоров'я, пов' язаної з наданням медичної допомоги та здійсненням медичного обслуговування; в) здійснення діяльності медичними працівниками як професіоналами або фахівцями [1, с. 63].

А. М. Коваль пропонує визначати медичну діяльність як проведення сукупності певних дій та застосування відповідних заходів уповноваженими суспільно-владними суб' єктами в організаційно-правовому порядку з метою забезпечення охорони здоров'я населення, підтримання його нормального життєдіяльного рівня, відновлення здоров'я особи, задоволення потреб людини в психологічній, психічній рівновазі, а також в естетично привабливому стані [2, с. 98]. Ураховуючи наведені вище визначення, для цілей нашого дослідження пропонуємо розуміти медичну діяльність як вид господарської діяльності у сфері охорони здоров'я, яка провадиться закладами охорони здоров'я і фізичними особами-пілприємцями та спрямована на профілактику, діагностику, лікування й реабілітацію у зв' язку з хворобами, травмами, отруєннями й патологічними станами, а також у зв' язку з вагітністю та пологами.

Термін «фармацевтична діяльність» використовується в Основах законодавства України про охорону здоров'я, хоча його визначення не відсутнє в цьому законодавчому акті. Однак окремі науковці, досліджуючи правове регулювання обігу лікарських засобів, запропонували власне визначення. Так С. В. Васильєв визначає фармацевтичну діяльність як промислове виробництво лікарських засобів, виготовлення лікарських засобів в умовах аптеки, оптову та роздрібну торгівлю лікарськими засобами, їх зберігання, перевезення, вивезення за кордон України, ввезення до України, зберігання, перевезення, виготовлення лікарських препаратів [3, с. 19]. Окремі визначення промислового виробнищтва лікарських засобів, виготовлення лікарських засобів в умовах аптеки, оптової та роздрібної торгівлі лікарськими засобами закріплені в Ліцензійних умовах провадження господарської діяльності з виробництва лікарських засобів, оптової та роздрібної торгівлі лікарськими засобами, імпорту лікарських засобів, затверджених постановою Кабміну від 30 листопада 2016 року. Вважаємо, що запропоноване С. В. Васильєим визначення фармацевтичної діяльності цілком відповідає меті нашого дослідження.

Правову основу здійснення медичної і фармацевтичної діяльності складають законодавчі і підзаконні акти, які регулюють як загальні засади здійснення такої діяльності, так і специфіку ії ліцензування, правовий статус закладів охорони здоров'я та фармацевтичних організацій, правовий статус медичних і фармацевтичних працівників, особливості здійснення державного нагляду у сфері медичної і фармацевтичної діяльності, специфіку державного управління у сфері охорони здоров' я.

Загальні засади здійснення медичної і фармацевтичної діяльності встановлені в Законі України «Про лікарські засоби», Основах законодавства України про охорону здоров' я, Законі України «Про державні фінансові гарантії медичного обслуговування населення». Зокрема, Закон України «Про лікарські засоби» встановлює специфіку створення, проведення клінічних і доклінічних випробувань, державної реєстрації, виробництва, реалізації, контролю якості, ввезення в Україну або вивезення з України лікарських засобів [7]. В Основах законодавства України про охорону здоров'я закріплені права та обов' язки громадян у сфері охорони здоров'я, правові основи надання медичної допомоги, організащії системи охорони здоров'я, медичної і фармацевтичної діяльності [5]. У Законі України «Про державні фінансові гарантії медичного обслуговування населення» передбачена програма медичних 
гарантій та засоби забезпечення їі реалізації, права та обов' язки пацієнта у сфері державних фінансових гарантій, контроль та відповідальність за дотримання законодавства у даній сфері [8]. Отже, указані законодавчі акти встановлюють основні принципи роботи медичної і фармацевтичної галузей.

Основу правового регулювання ліцензування медичної і фармацевтичної діяльності складають Закон України «Про ліцензування певних видів господарської діяльності», Ліцензійні умови провадження господарської діяльності з виробнищтва лікарських засобів, оптової та роздрібної торгівлі лікарськими засобами, імпорту лікарських засобів, затверджені постановою Кабміну від 30 листопада 2016 року (далі - Ліцензійні умови фармацевтичної діяльності), та Ліцензійні умови медичної діяльності.

У Законі України «Про ліцензування певних видів господарської діяльності» встановлено перелік видів діяльності, яка підлягає ліцензуванню, порядок оформлення і подання документів до органу ліцензування, порядок розгляду поданих документів і прийняття рішення про видачу ліцензії [9]. У Ліцензійні умовах фармацевтичної діяльності встановлено спеціальні організаційні, кадрові, технічні вимоги для отримання ліцензії на виробнищтво, виготовлення, оптову або роздрібну торгівлю лікарськими засобами [10]. Ліцензійні умови медичної діяльності передбачають спеціальні організаційні, кадрові і технологічні вимоги до закладів охорони здоров' я [6]. Отже, вказані законодавчі і підзаконні акти регулюють як загальні засади ліцензування господарської діяльності, так і специфіку ліцензування медичної і фармацевтичної діяльності. Особливості ліцензування полягають у наявності певних організаційних, технічних та кадрових вимог до кожного із видів діяльності.

Правовий статус закладів охорони здоров'я та фармацевтичних організацій визначено законодавчими та підзаконними актами. В абз. 2 ч. 1 ст. 3 Основ законодавства України про охорону здоров'я закріплено поняття закладу охорони здоров'я. У ст. 16 Основ встановлено форми власності, організаційно-правові форми та вимоги до керівника закладу охорони здоров'я [5]. Перелік закладів охорони здоров'я передбачено наказом Міністерства охорони здоров'я України (далі - МОЗ України) «Про затвердження переліків закладів охорони здоров'я, лікарських, провізорських посад, посад молодших спеціалістів з фармацевтичною освітою, посад професіоналів у галузі охорони здоров'я та посад фахівців у галузі охорони здоров'я в закладах охорони здоров' я» від 12 листопада 2002 року. У цьому наказі перелічені такі заклади охорони здоров'я, як госпіталі, лікарні, лікувально-діагностичні центри, медичні центри, перинатальні центри, пологові будинки, диспансери, центри реабілітації та профілактичні центри [11]. Правовий статус аптек, аптечних пунктів, аптечних кіосків, аптечних складів, виробників та імпортерів лікарських засобів встановлений у Ліцензійних умовах фармацевтичної діяльності. Цей підзаконний акт передбачає вимоги до обладнання, площі приміщень та персоналу названих фармацевтичних організацій [9]. Отже, особливості правового статусу як закладів охорони здоров'я, так і фармацевтичних організацій закріплені у відповідних підзаконних актах. Ці особливості полягають у спеціальних вимогах до їх обладнання, приміщень та персоналу.

Правовий статус медичних і фармацевтичних працівників встановлено в розділі Х Основ законодавства України про охорону здоров'я. Цей розділ визначає по- 
рядок підготовки і перепідготовки медичних і фармацевтичних працівників, їх професійні права та обов' язки, правові обмеження, встановлені під час здійснення ними професійної діяльності [5]. Перелік лікарських посад у закладі охорони здоров' я та Перелік провізорських посад у закладі охорони здоров'я затверджені наказом МO3 України від 28 жовтня 2002 року. Цей наказ визначає ті посади, які існують в закладі охорони здоров'я і на яких можуть працювати особи з медичною або фармацевтичною освітою [12].

Медичні та фармацевтичні працівники можуть бути притягнуті до кримінальної відповідальності за неналежне виконання своїх професійних обов' язків, внаслідок чого було завдано шкоду пацієнту. Серед статей КК України, що передбачають відповідальність медичних або фармацевтичних працівників, варто назвати такі:

- ст. 131 КК України - «Неналежне виконання медичним, фармацевтичним або іншим працівником своїх професійних обов' язків внаслідок недбалого чи несумлінного ставлення до них, що спричинило зараження особи вірусом імунодефіциту людини чи іншої невиліковної інфекційної хвороби»;

- ст. 139 КК України - «Ненадання допомоги хворому медичним працівником»;

- ст. 140 КК України - «Неналежне виконання професійних обов' язків медичним або фармацевтичним працівником»;

- ст. 141 КК України - «Порушення прав пацієнта» [13].

Таким чином, правовий статус медичного і фармацевтичного працівника характеризується як особливими професійними правами й обов' язками, так і специфічними підставами для притягнення до кримінальної відповідальності за неналежне виконання своїх професійних обов' язків.

Правову основу здійснення державного нагляду у сфері медичної і фармацевтичної діяльності складають Закон України «Про основні засади державного нагляду (контролю) у сфері господарської діяльності», який регулює загальні підстави та порядок здійснення державного нагляду в будь-якій галузі економіки щодо будьякої організації. Особливості правового регулювання державного нагляду у сфері медичної діяльності встановлюються такими підзаконними актами, як:

1) Критерії, за якими оцінюється ступінь ризику від провадження господарської діяльності з медичної практики і визначається періодичність проведення планових заходів державного нагляду (контролю) МО3 України, затверджені постановою Кабміну від 18 грудня 2018 року № 1163 [14];

2) Порядок контролю якості медичної допомоги, затверджений наказом MO3 України від 28 вересня 2012 року № 752 [15];

3) Порядок контролю за додержанням ліцензійних умов провадження певних видів господарської діяльності в галузі охорони здоров'я, що ліцензуються, затверджений наказом МОЗ України від 10 лютого 2011 року [16].

Специфіка правового регулювання державного нагляду у сфері фармацевтичної діяльності закріплена в таких підзаконних актах, як:

1) Порядок контролю за додержанням Ліцензійних умов провадження господарської діяльності з виробництва лікарських засобів, оптової, роздрібної торгівлі лікарськими засобами, затверджений наказом МОЗ України від 31 жовтня 2011 р. [17];

2) Порядок контролю якості лікарських засобів під час оптової та роздрібної торгівлі, затверджений наказом МОЗ України від 26 листопада 2014 р. [18]; 
3) Порядок відбору зразків лікарських засобів для лабораторного аналізу під час здійснення державного контролю якості таких засобів, затверджений постановою Кабміну від 3 лютого 2010 р. [19].

Отже, існує низка підзаконних актів Кабміну та МO3 України, які регулюють специфіку здійснення державного нагляду у сфері медичної та фармацевтичної діяльності. Вони встановлюють особливості здійснення пращівниками контролюючих органів заходів державного нагляду у сфері медичної та фармацевтичної діяльності.

Низка законодавчих і підзаконних актів складають правову основу державного управління у сфері охорони здоров'я. Зокрема, у ст. 15 Основ законодавства України про охорону здоров'я визначено органи державної влади, які забезпечують реалізацію державної політики у сфері охорони здоров' я [5]. Правовий статус, компетенщію і повноваження MO3 України визначено у відповідному Положенні, затвердженому постановою Кабміну від 25 березня 2015 року. Повноваження місцевих адміністрацій у галузі охорони здоров' я встановлені у ст. 22 Закону України «Про місцеві державні адміністрації. Передбачено, що місцева державна адміністрація вживає заходів до збереження мережі закладів охорони здоров'я, запобігання інфекційним захворюванням, епідеміям, епізоотіям та їх ліквідації; організовує роботу медичних закладів по наданню допомоги населенню [20]. Згідно зі ст. 32 Закону України «Про місцеве самоврядування», до відання виконавчих органів сільських, селищних, міських рад належить управління закладами охорони здоров'я, забезпечення в межах наданих повноважень доступності й безоплатності медичного обслуговування на відповідній території, забезпечення розвитку всіх видів медичного обслуговування [21].

Висновки. Підбиваючи підсумки, необхідно зазначити, що медичну діяльність варто визначати як вид господарської діяльності у сфері охорони здоров'я, яка провадиться закладами охорони здоров'я і фізичними особами-підприємцями, та спрямована на профілактику, діагностику, лікування й реабілітацію у зв' язку з хворобами, травмами, отруєннями й патологічними станами, а також у зв'язку з вагітністю та пологами. Сутність фармацевтичної діяльності варто розуміти як промислове виробнищтво лікарських засобів, виготовлення лікарських засобів в умовах аптеки, оптову та роздрібну торгівлю лікарськими засобами, їx зберігання, перевезення, вивезення за кордон України, ввезення до України, зберігання, перевезення, виготовлення лікарських препаратів.

Правову основу медичної і фармацевтичної діяльності складають законодавчі акти та підзаконні акти Кабміну і МОЗ України. За предметом правового регулювання ці законодавчі та підзаконні акти можна поділити на такі групи: 1) встановлюють загальні засади здійснення медичної і фармацевтичної діяльності; 2) закріплюють порядок ліцензування медичної і фармацевтичної діяльності; 3) передбачають правовий статус закладів охорони здоров'я та фармацевтичних організацій; 4) визначають правовий статус медичних і фармацевтичних працівників; 5) закріплюють особливості здійснення державного нагляду у сфері медичної і фармацевтичної діяльності; 6) встановлюють специфіку державного управління у сфері охорони здоров'я.

Вбачається, що перспективним напрямком подальших наукових досліджень $\epsilon$ вивчення і запозичення позитивного зарубіжного досвіду адміністративно-правових засад здійснення медичної і фармацевтичної діяльності з метою його подальшої 
інтеграції в законодавство України. Це сприятиме покращенню системи законодавства, що регулює вітчизняну медичну і фармацевтичну діяльність.

\section{Використані джерела:}

1. Загиней 3. В., Шмаль Л. І. Медична практика як дозволений вид діяльності в антикорупщійному законодавстві України. Науковий часопис Національної академї̈ прокуратури Украӥни. 2017. № 2. С. 51-66.

2. Коваль А. М. Щодо питання про правове регулювання отримання медичної допомоги та медичних послуг. Вісник прокуратури. 2010. № 1(103). С. 94-99.

3. Васильв С. В. Законодавче закріплення поняття «фармацевтична діяльність» як передумова підвищення ефективності державного управління у сфері обігу лікарських засобів. Вісник Харківського нациінального університету внутрішніх справ. 2011. № 4. С. 14-20.

4. Teremetskyi V.I., Dmytrenko E. S., Burya L. V., Grynenko S. O., Kovalenko E. V. Health Care Sector's Financial, Civil, Criminal and Administrative Liability in EU Member States and Ukraine: Results of Comparative Research. Georgian Medical News № 5 (302) 2020. P. 160-167.

5. Основи законодавства України про охорону здоров'я: Закон України від 19.11.1992 № 2801-XII. URL:https:/ /zakon.rada.gov.ua/laws/show/2801-12\#Text. (дата звернення: 25.08.2020).

6. Про затвердження Ліцензійних умов провадження господарської діяльності з медичної практики: постанова Кабінету Міністрів України від 02.03.2016 № 285. URL:https:/ / zakon. rada.gov.ua/laws/show/285-2016-п\#Техt. (дата звернення: 25.08.2020).

7. Про лікарські засоби: Закон України від 04.04. 1996 № 123/96-BP. URL:https:/ / zakon. rada.gov.ua/laws/show/123/96-вр\#Техt. (дата звернення: 25.08.2020).

8. Про державні фінансові гарантії медичного обслуговування населення: Закон України від 19.10.2017 № 2168-VIII. URL: https:/ / zakon.rada.gov.ua/laws/show/2168-19\#Text. (дата звернення: 15.08.2020).

9. Про ліщензування видів господарської діяльності: Закон України від 02.03.2015 № 222VIII. URL:https:/ /zakon.rada.gov.ua/laws/show/222-19\#Text. (дата звернення: 25.08.2020).

10. Про затвердження Ліцензійних умов провадження господарської діяльності з виробнищтва лікарських засобів, оптової та роздрібної торгівлі лікарськими засобами, імпорту лікарських засобів (крім активних фармацевтичних інгредієнтів): постанова Кабінету Міністрів України від 30.11.2016 №929. URL:https://zakon.rada.gov.ua/laws/show/929-2016-п\#Text. .(дата звернення: 25.08.2020).

11. Про затвердження переліків закладів охорони здоров'я, лікарських, провізорських посад, посад молодших спеціалістів з фармацевтичною освітою, посад професіоналів у галузі охорони здоров'я та посад фахівців у галузі охорони здоров'я з у закладах охорони здоров'я: наказ Міністерства охорони здоров'я України від 12.11.2002 №385. URL:https:/ /zakon.rada.gov. ua/ laws/show/z0892-02\#Техt. (дата звернення: 25.08.2020).

12. Про затвердження переліку провізорських посад з у закладах охорони здоров'я: наказ Міністерства охорониздоров'я України від 12.11.2002 №385.URL:https:/ / zakon. rada.gov.ua/laws/ show/z0892-02\#Tехt. (дата звернення: 25.08.2020).

13. Кримінальний кодекс України: Закон України від 05.04.2001 № 2341-III. URL:https:/ / zakon.rada gov.ua/laws/show/2341-14\#Tехt. (дата звернення: 25.08.2020).

14. Про затвердження Критеріїв, за якими оцінюється ступінь ризику від провадження господарської діяльності з медичної практики і визначається періодичність проведення планових заходів державного нагляду (контролю) Міністерством охорониздоров'я України: постанова Кабінету Міністрів України від 18.12.2018 №1163. URL:https:/ /zakon.rada.gov.ua/laws/show/11632018-п\#Техt. (дата звернення: 25.08.2020). 
15. Про затвердження Порядку контролю якості медичної допомоги: наказ МОЗ України від 28.09.2012 № 752. URL:https:/ / zakon.rada.gov.ua/laws/show/z1996-12\#Tехt. (дата звернення: 25.08.2020).

16. Про затвердження Порядку контролю за додержанням ліщензійних умов провадження певних видів господарської діяльності в галузі охорониздоров'я, що ліцензуються: наказ MO3 України від 10.02.2011 № 80. URL:https://zakon. rada.gov.ua/laws/ show/z063411\#Text. (дата звернення: 25.08.2020).

17. Про затвердження Порядку контролю за додержанням Ліцензійних умов провадження господарської діяльності з виробництва лікарських засобів, оптової, роздрібної торгівлі лікарськими засобами: наказ Міністерства охорони здоров'я України від 31.10.2011 № 724 URL:https:/ / zakon.rada.gov.ua/laws/show/z1421-11\#Text. (дата звернення: 25.08.2020).

18. Про затвердження Порядку контролю якості лікарських засобів під час оптової та роздрібної торгівлі: наказ Міністерства охорони здоров'я України від 29.09.2014 №677. URL:https:/ /zakon.rada.gov.ua/laws/show/z1515-14\#Text. (дата звернення: 25.08.2020).

19. Деякі питання державного контролю якості лікарських засобів: Постанова Кабінету Міністрів України від 03.02.2010 № 260. URL:https://zakon.rada.gov.ua/laws/show/260-2010п\#Техt. (дата звернення: 25.08.2020).

20.Про місцеві державні адміністрації: Закон України від 09.04.1999 №586-XIV. URL:https:/ /zakon.rada.gov.ua/laws/show/586-14\#Text. (дата звернення: 25.08.2020).

21.Про місцеве самоврядування: Закон Украӥни від 21.05.1997 № 280/97-BP. URL:https:// zakon.rada.gov.ua/laws/show/280/97-вр\#Техt. (дата звернення: 25.08.2020).

\section{References:}

1. Zahynei, Z. V., Shmal, L. I. (2017). Medychna praktyka yak dozvolenyi vyd diialnosti v antykoruptsiinomu zakonodavstvi Ukrainy. Naukouyi chasopys Natsionalnoi akademii prokuratury UkrainyScientific journal of the National Academy of the Prosecutor's Office of Ukraine, 2, 51-66. [in Ukrainian].

2. Koval, A. M. (2010). Shchodo pytannia pro pravove rehuliuvannia otrymannia medychnoi dopomohy ta medychnykh posluh. Visnyk prokuratury- Bulletin of the prosecutor's office, 1(103), 94-99. [in Ukrainian].

3. Vasyliev, S. V. (2011). Zakonodavche zakriplennia poniattia «farmatsevtychna diialnist» yak peredumova pidvyshchennia efektyvnosti derzhavnoho upravlinnia u sferi obihu likarskykh zasobiv. Visnyk Kharkioskoho natsionalnoho universytetu vnutrishnikh sprav - Bulletin of Kharkiv National University of Internal Affairs, 4, 14-20. [in Ukrainian].

4. Teremetskyi, V. I., Dmytrenko, E. S., Burya, L. V., Grynenko, S. O., Kovalenko, E. V. (2020). Health Care Sector's Financial, Civil, Criminal and Administrative Liability in EU Member States and Ukraine: Results of Comparative Research. Georgian Medical News, 5 (302), 160-167. [in English].

5. Osnovy zakonodavstva Ukrainy pro okhoronu zdorovia: Zakon Ukrainy vid 19.11.1992 № 2801-XII. (1992) N. p. URL:https:/ / zakon.rada.gov.ua/laws/show/2801-12\#Text. [in Ukrainian].

6. Pro zatverdzhennia Litsenziinykh umov provadzhennia hospodarskoi diialnosti $\mathrm{z}$ medychnoi praktyky: postanova Kabinetu Ministriv Ukrainy vid 02.03.2016 № 285. (2016) N. p. URL:https://zakon.rada.gov.ua/laws/show/285-2016-п\#Text. [in Ukrainian].

7. Про лікарські засоби: Закон Украӥни від 04.04. Pro likarski zasoby: Zakon Ukrainy vid 1996 № 123/96-BP. (1996) N. p. URL:https:/ / zakon.rada.gov.ua/laws/show/123/96-вp\#Text. [in Ukrainian].

8. Pro derzhavni finansovi harantii medychnoho obsluhovuvannia naselennia: Zakon Ukrainy vid 19.10.2017№ 2168-VIII.92017) N. p. URL:https:/ / zakon.rada.gov.ua/laws/show/2168-19\#Text. [in Ukrainian]. 
9. Pro litsenzuvannia vydiv hospodarskoi diialnosti: Zakon Ukrainy vid 02.03.2015 № 222-VIII. (2015) URL:https:/ / zakon.rada.gov.ua/laws/show/222-19\#Text. [in Ukrainian].

10. Pro zatverdzhennia Litsenziinykh umov provadzhennia hospodarskoi diialnosti $\mathrm{z}$ vyrobnytstva likarskykh zasobiv, optovoi ta rozdribnoi torhivli likarskymy zasobamy, importu likarskykh zasobiv (krim aktyvnykh farmatsevtychnykh inhrediientiv): postanova Kabinetu Ministriv Ukrainy vid 30.11.2016 №929. (2016) N. p. URL:https://zakon.rada.gov.ua/laws/show/929-2016n\#Text. [in Ukrainian].

11. Pro zatverdzhennia perelikiv zakladiv okhorony zdorovia, likarskykh, provizorskykh posad, posad molodshykh spetsialistiv $\mathrm{z}$ farmatsevtychnoiu osvitoiu, posad profesionaliv $\mathrm{u}$ haluzi okhorony zdorovia ta posad fakhivtsiv $\mathrm{u}$ haluzi okhorony zdorovia $\mathrm{z} \mathrm{u}$ zakladakh okhorony zdorovia: nakaz Ministerstva okhorony zdorovia Ukrainy vid 12.11.2002 №385. (2002) N. p. URL:https:/ / zakon.rada.gov.ua/laws/show/z0892-02\#Text. [in Ukrainian].

12. Pro zatverdzhennia pereliku provizorskykh posad $\mathrm{z}$ u zakladakh okhorony zdorovia: nakaz Ministerstva okhorony zdorovia Ukrainy vid 12.11.2002 №385. (2002) N. p. URL:https:// zakon.rada.gov.ua/laws/show/z0892-02\#Text. [in Ukrainian].

13. Kryminalnyi kodeks Ukrainy: Zakon Ukrainy vid 05.04.2001 №2341-III. (2001) N. p. URL:https:/ / zakon.rada.gov.ua/laws/show/2341-14\#Text. [in Ukrainian].

14. Pro zatverdzhennia Kryteriiv, za yakymy otsiniuietsia stupin ryzyku vid provadzhennia hospodarskoi diialnosti z medychnoi praktyky i vyznachaietsia periodychnist provedennia planovykh zakhodiv derzhavnoho nahliadu (kontroliu) Ministerstvom okhorony zdorovia Ukrainy: postanova Kabinetu Ministriv Ukrainy vid 18.12.2018 №1163. (2018) N. p. URL:https:// zakon.rada.gov.ua/laws/ show/1163-2018-п\#Text. [in Ukrainian].

15. Pro zatverdzhennia Poriadku kontroliu yakosti medychnoi dopomohy: nakaz MOZ Ukrainy vid 28.09.2012 № 752. (2012) N. p. URL: https://zakon.rada.gov.ua/laws/show/z199612\#Text. [in Ukrainian].

16. Pro zatverdzhennia Poriadku kontroliu za doderzhanniam litsenziinykh umov provadzhennia pevnykh vydiv hospodarskoi diialnosti v haluzi okhorony zdorovia, shcho litsenzuiutsia: nakaz MOZ Ukrainy vid 10.02.2011 №80. (2011) N. p. URL:https:/ / zakon.rada.gov.ua/laws/show/z0634-11\#Text. in Ukrainian].

17. Pro zatverdzhennia Poriadku kontroliu za doderzhanniam Litsenziinykh umov provadzhennia hospodarskoi diialnosti z vyrobnytstva likarskykh zasobiv, optovoi, rozdribnoi torhivli likarskymy zasobamy: nakaz Ministerstva okhorony zdorovia Ukrainy vid 31.10.2011 № 724 . (2011) N. p. URL:https://zakon.rada.gov.ua/laws/show/z1421-11\#Text. [in Ukrainian].

18. Pro zatverdzhennia Poriadku kontroliu yakosti likarskykh zasobiv pid chas optovoi ta rozdribnoi torhivli: nakaz Ministerstva okhorony zdorovia Ukrainy vid 29.09.2014 № 677. (2014) N p. URL:https:// zakon.rada.gov.ua/laws/show/z1515-14\#Text. [in Ukrainian].

19. Deiaki pytannia derzhavnoho kontroliu yakosti likarskykh zasobiv: Postanova Kabinetu Ministriv Ukrainy vid 03.02.2010 № 260. (2010) N.p. URL:https:/ / zakon.rada.gov.ua/laws/show/2602010-п\#Text. [in Ukrainian].

20. Pro mistsevi derzhavni administratsii: Zakon Ukrainy vid 09.04.1999 № 586-XIV. (1999) N. p. URL:https:/ / zakon.rada.gov.ua/laws/show/586-14\#Text. [in Ukrainian].

21. Pro mistseve samovriaduvannia: Zakon Ukrainy vid 21.05.1997 № 280/97-BP. (1997) N. p. URL:https://zakon.rada.gov.ua/laws/show/280/97-вp\#Text. [in Ukrainian]. 
Ховпун А. С.,

кандидат юридических наук, доцент, заведующий кафедрой уголовного права, процесса и криминалистики Академии труда, социальных отношений и туризма

(г. Киев, Украина)

\section{АДМИНИСТРАТИВНО-ПРАВОВЫЕ ОСНОВЫ ОСУЩЕСТВЛЕНИЯ МЕДИЦИНСКОЙ И ФАРМАЦЕВТИЧЕСКОЙ ДЕЯТЕЛЬНОСТИ В УКРАИНЕ}

Статья посвящена правовым основам осуществления медицинской и фармацевтической деятельности в Украине. Определены понятия медицинской и фармацевтической деятельности. Приведенные законодательные и подзаконные акты, регулирующие лицензирование этой деятельности, правовой статус медицинских и фармацевтических работников, учреждений здравоохранения, фармацевтических организаций, специфика государственного надзора и государственного управления в указанных сферах общественной жизни. Выяснено, что специальными нормативно-правовыми актами, которые устанавливают особенности лицензирования медицинской и фармацевтической деятельности, есть соответствующие Лищензионные условия осуществления каждого из видов такой деятельности. Они закрепшяют организационные, технологические и кадровые требования к учреждениям здравоохранения и фармацевтических организаций. Определены нормативные основы правового статуса медицинских и фармацевтических работников. Акцентировано внимание на нормативной основе для привлечения к уголовной ответственности за ненадлежащее исполнение своих профессиональных обязанностей.

Ключевые слова: правовое регулирование, медицинская деятельность, фармацевтическая деятельность, лицензирование, правовой статус.

Khovpun O., Ph.D in Law, Chair of the Department of Criminal Law, Process and Criminology, Academy of Labour, Social Relations and Tourism

(Kyiv, Ukraine)

\section{ADMINISTRATIVE AND LEGAL PRINCIPLES OF CARRYING OUT MEDICAL AND PHARMACEUTICAL ACTIVITY IN UKRAINE}

The author of the article has proved that clear and high-quality normative regulation of any type of economic activity is the guarantee of ensuring the rights and legitimate interests of citizens while providing any services or performing works. Medical and pharmaceutical activities are no exception. Thus, the article is focused on establishing the legal principles of carrying out medical and pharmaceutical activities. The author of the article, based on the study of legislation and doctrinal developments of certain scholars, has clarified the concepts of medical and pharmaceutical activities; have determined the essential features that characterize medical practice.

The author of the article has studied the system of legislative and regulatory normative and legal acts regulating both the general principles of such activities and the specifics of its licensing, the legal status of health care institutions and pharmaceutical organizations, the legal status of medical and pharmaceutical employees, the peculiarities of carrying out state supervision in in the field of medical and pharmaceutical activities, the specifics of public administration in the health care sector. 
It has been clarified that the special regulatory acts that establish the specifics of licensing of medical and pharmaceutical activities are the relevant licensing conditions for each of these activities. They set organizational, technological and personnel requirements for healthcare institutions and pharmaceutical organizations.

The regulatory principles of the legal status of medical and pharmaceutical employees have been determined. The emphasis has been placed on the regulatory basis for criminal prosecution for improper performance of the professional duties.

It has been noted that legislative acts and bylaws of the Cabinet of Ministers of Ukraine and the Ministry of Health of Ukraine constitute the legal basis for medical and pharmaceutical activities. The author has offered to divide regulatory acts, which constitute the legal basis of medical and pharmaceutical activities, into groups according to the subject matter of legal regulation.

Keywords: legal regulation, medical activity, pharmaceutical activity, licensing, legal status.

DOI: 10.33766/2524-0323.91.205-217

УДК 351

В. Л. Федоренко,

доктор юридичних наук, професор, заслужений юрист України,

директор Науково-дослідного центру

судової експертизи з питань інтелектуальної власності

Міністерства юстиції Украӥни

(м. Київ, Україна)

e-mail:fedorenko900@gmail.com.

iDhttps://orcid.org/0000-0001-5902-1226

М. В. Федоренко,

магістр Національної академії державного управління

при Президентові України,

слухач магістратури (відділення «Право»)

Академії Леона Козьмінського

(м. Варшава, Республіка Польща)

e-mail:lermont98@gmail.com.

iDhttps://orcid.org/0000-0003-4392-7124

\section{СИСТЕМИ УПРАВЛІННЯ ДЕРЖАВНОЮ СЛУЖБОЮ В УКРАЇНІ ТА ПОЛЬЩ: ПОРІВНЯЛЬНО-ПРАВОВИЙ АСПЕКТ}

У статті аналізуються та порівнюються системи управління державною службою в Україні та Республіці Польща, їх внутрішня побудова та суб'єктний склад, а також досліджуються особливості функціонування цих двох систем. Обгрунтовується, що під системою органів управління державною службою в Україні слід розуміти систему законодавчо визначених та ієрархічно упорядкованих суб'єктів державного управління із загальною (Кабінет Міністрів України) та спеціальною (центральний орган виконавчої влади, що забезпечує формування й реалізує державну політику у сфері державної служби; Комісію з питань вищого корпусу державної служби та відповідні конкурсні комісії; керівників державної служби; служби управління персоналом) компетенцією, а також профільни x навчальних закладів (Національна академія державного управління при Президентові України й ін.) і наукових установ, та систему їх унормованих і взаємозумовлених функцій

() Федоренко В. Л.,

Федоренко М. В., 2020 